\title{
Southern African HIV Clinicians Society Guidance on the use of dolutegravir in first-line antiretroviral therapy
}

\begin{tabular}{|c|c|}
\hline Authors: & \\
\hline Michelle A. M & loorhouse ${ }^{1}$ (1) \\
\hline Sergio Carmo & $\mathrm{na}^{2}$ (1) \\
\hline Natasha Davie & $\mathrm{es}^{1}$ (1) \\
\hline Sipho Dlamini & 3 \\
\hline Cloete van Vu & uren $^{4}$ (1) \\
\hline Thandekile M & anzini $^{4}$ (1) \\
\hline Moeketsi Mat & $\mathrm{he}^{5}$ \\
\hline Yunus Moosa & \\
\hline Jennifer Nash & 4 (1) \\
\hline Jeremy $\mathrm{Nel}^{4}$ & \\
\hline Yoliswa Pakad & $\mathrm{e}^{4}$ \\
\hline Joana Woods & \\
\hline Gert van Zyl ${ }^{4}$ & \\
\hline Francesca Con & $\operatorname{tradie}^{1}$ \\
\hline Francois Vent & \\
\hline Graeme Mein & tjes $^{7}$ \\
\hline Affiliations: & \\
\hline $\begin{array}{l}{ }^{1} \text { Wits Reprod } \\
\text { and HIV Instit } \\
\text { Health Scienc } \\
\text { of the Witwat } \\
\text { South Africa }\end{array}$ & $\begin{array}{l}\text { uctive Health } \\
\text { ute, Faculty of } \\
\text { es, University } \\
\text { tersrand, }\end{array}$ \\
\hline${ }^{2}$ National Hea & Ith Laboratory \\
\hline Services, Sout & h Africa \\
\hline $\begin{array}{l}{ }^{2} \text { Department } \\
\text { University of } \\
\text { South Africa }\end{array}$ & $\begin{array}{l}\text { of Medicine, } \\
\text { Cape Town, }\end{array}$ \\
\hline $\begin{array}{l}{ }^{4} \text { Southern Afri } \\
\text { Clinicians Soci }\end{array}$ & can HIV \\
\hline $\begin{array}{l}{ }^{5} \text { Private Practi } \\
\text { South Africa }\end{array}$ & ice, Vereeniging, \\
\hline${ }^{6}$ Department & of Infectious \\
\hline $\begin{array}{l}\text { Diseases, Uni } \\
\text { KwaZulu-Nata }\end{array}$ & $\begin{array}{l}\text { versity of } \\
\text { I, South Africa }\end{array}$ \\
\hline $\begin{array}{l}{ }^{7} \text { Department } \\
\text { Institute of In } \\
\text { and Molecula } \\
\text { University of } \\
\text { South Africa }\end{array}$ & $\begin{array}{l}\text { of Medicine and } \\
\text { fectious Disease } \\
\text { r Medicine, } \\
\text { Cape Town, }\end{array}$ \\
\hline $\begin{array}{l}\text { Correspondin } \\
\text { Michelle Moo } \\
\text { mmoorhouse }\end{array}$ & $\begin{array}{l}\text { g author: } \\
\text { rhouse, } \\
\text { @wrhi.ac.za }\end{array}$ \\
\hline Read online: & \\
\hline 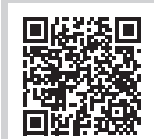 & $\begin{array}{l}\text { Scan this QR } \\
\text { code with your } \\
\text { smart phone or } \\
\text { mobile device } \\
\text { to read online. }\end{array}$ \\
\hline
\end{tabular}

The Southern African HIV Clinicians Society would like to update all HIV-treating clinicians with regard to the use of dolutegravir in women of childbearing potential (WOCP).

In preliminary data from the Tsepamo study in Botswana, it was found that $0.94 \%$ (95\% confidence interval [CI]: $0.37-2.4$ ) of babies $(4 / 426)$ born to women who were taking dolutegravir periconception had neural tube defects (NTDs), compared with $0.1 \%$ of babies $(14 / 11$ 173) of women taking other antiretroviral drugs (ARVs) in the periconception period. ${ }^{1}$ No NTDs were observed in pregnancies where dolutegravir was initiated later in pregnancy. Further data from the Tsepamo study were presented at AIDS 2018: the updated number of NTDs with periconception dolutegravir exposure in the Tsepamo cohort is $4 / 596,0.67 \%$ (95\% CI: 0.26 to 1.7 ). The next formal analysis will occur after 31 March 2019 and will include women exposed to dolutegravir from conception before the recent change in guidance. Tsepamo plans to expand the number of study sites, increasing the coverage from $45 \%$ to $72 \%$ of births in Botswana with a projected denominator of over 1200 by March 2019. ${ }^{1}$

Prior to the data from Botswana, reproductive toxicology studies had not shown any concerning findings. To date, other data on the use of dolutegravir in pregnancy, including data from the Antiretroviral Pregnancy Registry, clinical trials and post-marketing surveillance, have not indicated a risk of NTDs.

The World Health Organization (WHO) launched new interim guidance on HIV treatment at AIDS 2018, recommending dolutegravir for everyone aged six years and above. Based on limited data, WHO notes that there are safety concerns regarding the use of dolutegravir periconception. ${ }^{2}$

World Health Organization recommendations for WOCP include the following:

- Dolutegravir-based first-line antiretroviral therapy (ART) is recommended for:

- all pregnant (from eight weeks after conception) and breastfeeding women and adolescent girls $^{2,3}$

- women and adolescent girls with effective contraception or not of childbearing potential.

- Women and adolescent girls of childbearing potential who want to become pregnant or have no effective contraception should use efavirenz-based $(600 \mathrm{mg})$ first-line ART. ${ }^{2,3}$

- Consider the balance of benefits and risks, including fertility levels, contraceptive availability and coverage, pretreatment resistance to non-nucleoside reverse transcriptase inhibitors at the population level, drug availability and the maternal and infant toxicity profile when selecting the optimal ARV drug regimen for WOCP.,3

- Strengthen the integration of sexual and reproductive health services within HIV treatment programmes to ensure reliable and consistent access to contraception for women and adolescent girls living with HIV., ${ }^{2,3}$

- A woman-centred approach should be adopted: healthcare providers should provide women with information and options to allow for informed choices about using lifelong ART regimens. ${ }^{2,3}$

\section{Southern African HIV Clinicians Society guidance}

- A woman-centred approach should be adopted: healthcare providers should give women information and options to allow for informed choices about using lifelong ART regimens.

Dates: Received: 20 Sept. 2018 | Accepted: 20 Sept. 2018 | Published: 17 Oct. 2018

How to cite this article: Moorhouse MA, Carmona S, Davies N, et al. Southern African HIV Clinicians Society Guidance on the use of dolutegravir in first-line antiretroviral therapy. S Afr J HIV Med. 2018;19(1), a917. https://doi.org/10.4102/sajhivmed.v19i1.917

Copyright: @ 2018. The Authors. Licensee: AOSIS. This work is licensed under the Creative Commons Attribution License. 
- Dolutegravir-based first-line ART is recommended for:

- all pregnant (from eight weeks after conception) and breastfeeding women and adolescent girls

- women and adolescent girls on effective contraception or not of childbearing potential.

- Women and adolescent girls of childbearing potential who want to become pregnant or have no effective contraception should be adequately counselled about the potential risks and benefits of dolutegravir- versus efavirenz-based ART and should be offered the choice of both treatments. This discussion should be documented, preferably along with consent from those women opting for dolutegravir-based ART.

- If pregnancy is confirmed in the first eight weeks while a woman is taking dolutegravir, she should be adequately counselled about the potential risks and benefits of dolutegravir- versus efavirenz-based ART and should offered the choice of both treatments. This discussion should be documented, preferably along with consent from those women opting for dolutegravir-based ART. The risk and benefits of switching during pregnancy should also be discussed. Switching is associated with a small risk of viraemia in a previously virologically suppressed patient, which may result in risk of motherto-child transmission and resistance.

While this is an early signal, it warrants careful pharmacovigilance and further evaluation. As more information becomes available, we will update our guidance.

\section{References}

1. Zash R, Holmes L, Makhema J, Diseko M, Jacobson DL, Mayondi G, et al. Surveillance for neural tube defects following antiretroviral exposure from conception, the Tsepamo study (Botswana). AIDS 2018. 2018 Jul 23-27. Symposium session TUSY1.

2. WHO. What's new in WHO treatment guidelines: The role of dolutegravir in firstand second-line and new directions in early infant diagnosis. Session MOSA26.

3. WHO policy brief. Antiretroviral regimens for treating and preventing HIV infection and update on early infant diagnosis of HIV [homepage on the Internet]. July 2018 [cited]. Available from: http://apps.who.int/iris/bitstream/handle/10665/273129/ WHO-CDS-HIV-18.19-eng.pdf 